\title{
IDENTIFICATION OF ROCKS AND THEIR QUARTZ CONTENT IN AMARKANTAK, INDIA USING ASTER TIR DATA
}

\author{
S. Guha ${ }^{1, *}$, H. Govil ${ }^{1}$, M. Tripathi ${ }^{1}$, M. Besoya ${ }^{1}$ \\ ${ }^{1}$ Department of Applied Geology, National Institute of Technology Raipur, Raipur, India- (subhanilguha, himgeo, tripathi.mahesh1, \\ geniousmonika11)@gmail.com
}

Commission V, SS: Natural Resources Management

KEY WORDS: Quartz, Principal component analysis, Thermal infrared, ASTER

\begin{abstract}
:
Quartz $\left(\mathrm{SiO}_{2}\right)$ abundance in rock is an important indicator of mineralization in many metal deposits and quartz detection has a great role in mineral exploration. The present study identified the quartz contained rocks in Amarkantak region, India applying thermal infrared bands (bands 10-14) of the Advanced Spaceborne Thermal Emission and Reflection Radiometer (ASTER) image. After atmospheric correction, principal component analysis technique was applied on the TIR bands and the resulting principal component images were analyzed. The three optimal principal components were selected based on the spectral interaction strength and the eigenvalues of each band of the ASTER data. The result presented that extrusive igneous rock and carbonate sedimentary rocks are quartz-poor while sedimentary rocks made up of organic particles and sandstone is quartz-rich.
\end{abstract}

\section{INTRODUCTION}

Hyperspectral and multispectral satellite images were frequently applied for extracting lithological and mineralogical information (vanderMeer et al. 2012; Pour and Hashim 2012). Visible-near-infrared (VNIR) and short wave infrared (SWIR) regions of electromagnetic spectrum is not so useful for detecting quartz and feldspar minerals (Lyon, 1972; Salisbury and Walter, 1989) whereas thermal infrared (TIR) region is extremely useful for the delineation of the aforesaid minerals because of the vibration of $\mathrm{Si}-\mathrm{O}$ bonds (Farmer, 1974; Kahle, 1976; Lyon, 1972). Lithological mapping is an important task of geological exploration. Remote sensing techniques plays a significant role in lithological and minerological mapping. TIR region are less studied than VNIR or SWIR regions for mineral exploration due to the less availability of satellite sensors in TIR domain. Advanced Spaceborne Thermal Emission and Reflection Radiometer (ASTER) data is considered as one of the most effective data for lithological and mineralogical mapping due to its high sensitivity to rock mineral elements (alunite, kaolinite, calcite, dolomite, chlorite, talc, muscovite, etc.) and low-cost (Tornabeen et al. 2005; Gad and Kusky 2007). ASTER data has three VNIR bands, six SWIR bands, and five TIR bands. Based on the analysis of ASTER TIR band based emissivity spectra of rocks, Ninomiya et al. (2005) have proposed few popular spectral indices for the mapping of quartz, carbonate, and mafic rocks using ASTER data. Many important geological units were also mapped using TIR bands of ASTER data using emissivity as a parameter (Bertoldi et al., 2011; Ding et al., 2014; Matar and Bamousa, 2013; Ninomiya et al., 2005; Rowan et al., 2005). However, mineralogically sensitive indices often derived significant results in terms of delineating mineralogical contrast by highlighting variations in thermal emissivity of terrain elements recorded in selected numbers of bands. The term granitoids include family of felsic igneous rocks viz. alkali granites, granites, granodiorites, tonalities; which are essentially constituted with quartz, varied proportions of alkali feldspar and plagioclase feldspar (Bose, 1997). Alkali feldspar rich granite is characterised with high ratio of alkali feldspar to plagioclase feldspar content whereas the ratio is progressively lower in granodiorite and tonalite (Bose, 1997). Mafic mineral content (biotite, hornblende etc.) is low in granitoids in general. However, mafic mineral abundances are also progressively higher as we go from granite to tonalite in granite-granodiorite-tonalite sequence.

In this study, ASTER TIR bands (bands 10-14) were applied to quartz-rich and quartz-poor rocks mapping in Amarkantak using principal component analysis (PCA) technique.

\section{MATERIALS AND METHODS}

ASTER image of 23 February 2003 was used in this study (Fig. 1). Only the ASTER thermal infrared (TIR) bands were used in this study because within $8-14 \mu \mathrm{m}$, quartz minerals exhibit strong vibrational absorption feature spectrally (Pour and Hashim 2012a, 2012b). Specification of ASTER thermal bands was provided in Table 1 . We analyzed resampled (i.e., resampled to the bandwidth of ASTER thermal bands) laboratory derived emissivity spectra of quartz, orthoclase, and plagioclase minerals; three key minerals of granitoids The lithologic and mineral map prepared from satellite data were widely used to for the visual validation of the rock element identification. To differentiate between vegetation area and outcrop areas, normalized difference vegetation index (NDVI) was used (Fig. 2). The vegetation and cloud affected areas were masked from the TIR bands and only the outcrop area was subjected to PCA.

\footnotetext{
* Corresponding author
} 


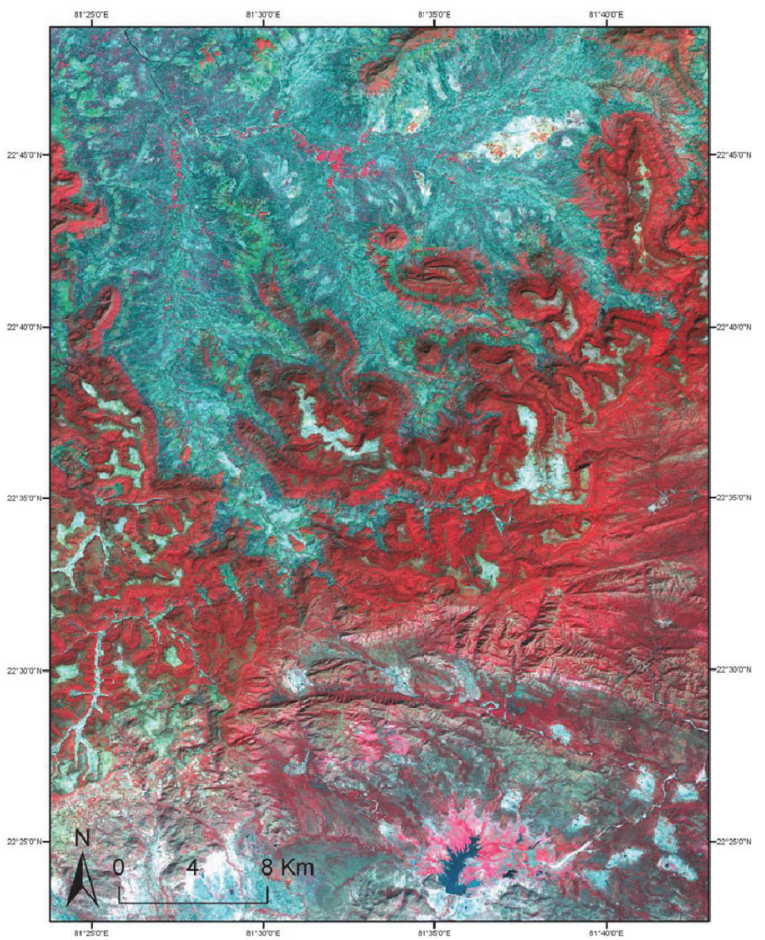

Figure 1. Location of the study area

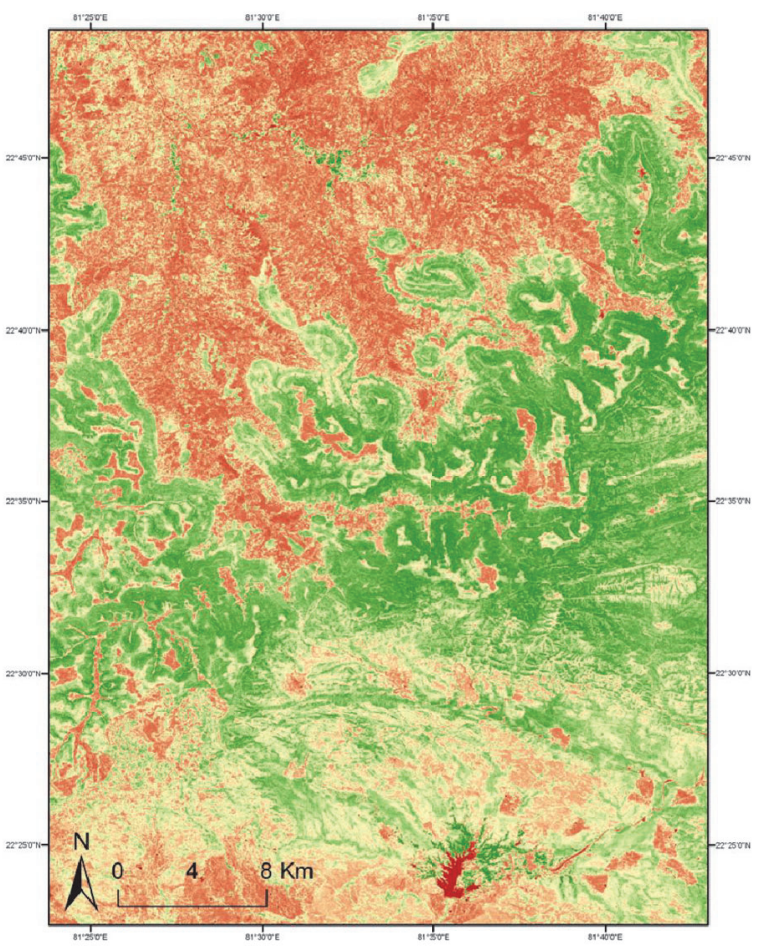

Figure 2. NDVI image

It was observed that quartz was characterized with emissivity minima at band 12 (for quartz) with the relative high in emissivity in band 10 and band 13 of ASTER bands. Feldspar is characterized with lower emissivity (for both plagioclase and orthoclase feldspar but the emissivity minima were more intense for orthoclase feldspar or K-feldspar) in band 11 than band 10 of ASTER thermal bands (Fig. 3). It is also known that mafic minerals and rocks are known for their emissivity minima in band 13 of ASTER sensor than band 12 and band 14 (Son et al., 2014). It was observed that emissivity spectra of quartz and feldspar had a reverse trend in band 11 and band 12 (Son et al., 2014). Therefore, emissivity minima of feldspar would be nullified by the high emissivity of quartz in band 11 with respect to band 12 if quartz and feldspar are present in the same rock. Based on the above observations on emissivity spectra of constituent minerals of granitoids and their respective image spectra, the following indices were derived to delineate quartz, feldspar and mafic mineral variation in granitoids based on the processing of ASTER bands.

\begin{tabular}{|c|c|c|c|c|c|}
\hline $\begin{array}{l}\text { ASTER } \\
\text { granule } \\
\text { ID }\end{array}$ & $\begin{array}{l}\text { Sen } \\
\text { sor } \\
\text { typ } \\
\text { e }\end{array}$ & $\begin{array}{l}\text { Band } \\
\text { numb } \\
\text { er }\end{array}$ & $\begin{array}{l}\text { Spectra } \\
1 \\
\text { wavele } \\
\text { ngth } \\
(\mu \mathrm{m})\end{array}$ & $\begin{array}{l}\text { Spatia } \\
1 \\
\text { resolu } \\
\text { tion } \\
(\mathrm{m})\end{array}$ & $\begin{array}{l}\text { Radio } \\
\text { metric } \\
\text { resoluti } \\
\text { on }\end{array}$ \\
\hline \multirow{5}{*}{$\begin{array}{l}\text { ASTB03 } \\
0223051 \\
412 \\
\text { Date:23 } \\
\text { Feb 2003 }\end{array}$} & TIR & 10 & $\begin{array}{l}8.125- \\
8.475\end{array}$ & 90 & 12 bits \\
\hline & TIR & 11 & $\begin{array}{l}8.475- \\
8.825\end{array}$ & 90 & 12 bits \\
\hline & TIR & 12 & $\begin{array}{l}8.925- \\
9.275 \\
\end{array}$ & 90 & 12 bits \\
\hline & TIR & 13 & $\begin{array}{l}10.25- \\
10.95\end{array}$ & 90 & 12 bits \\
\hline & TIR & 14 & $\begin{array}{l}10.95- \\
11.65 \\
\end{array}$ & 90 & 12 bits \\
\hline
\end{tabular}

Table 1. Specification of ASTER TIR bands

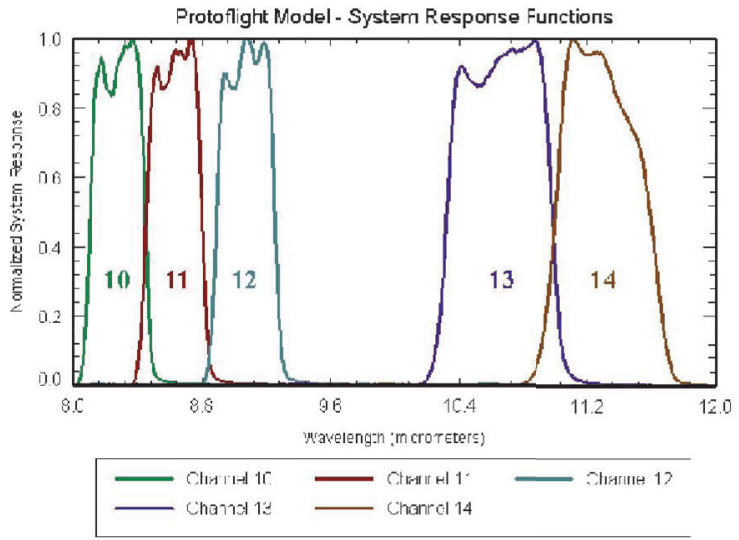

Figure 3. Spectral ASTER TIR bands in the wavelength of the electromagnetic spectrum (Source: NASA Jet Propulsion Laboratory)

Quartz has no such spectral absorption features in the visible and near infrared or shortwave infrared spectrum but have a very powerful molecular absorption features in TIR $(8-10 \mu \mathrm{m})$ bands. We used PCA transformation of the five ASTER TIR bands (bands 10-14) to generate five different principal components (PC1, PC2, PC3, PC4, and PC5). The eigenvalues were analyzed to select the most significant three PCs components for identifying quartz richness (Pour and Hashim 2011a). The three selected PCs (PC1, PC3, and PC4) were used to generate RGB false colour composite (FCC) of the study area (Fig. 4). After visual examination of the FCC relative to the existing map, the PCs composite image was classified into four different rock types [quartz concentration (quartz-rich and quartz-poor), quartz-rich sedimentary rock, quartz-poor igneous rock, and quartz-poor limestone)] based on quartz richness using and maximum likelihood supervised classification method. Finally, the accuracy of the classified image was assessed through error matrix. 


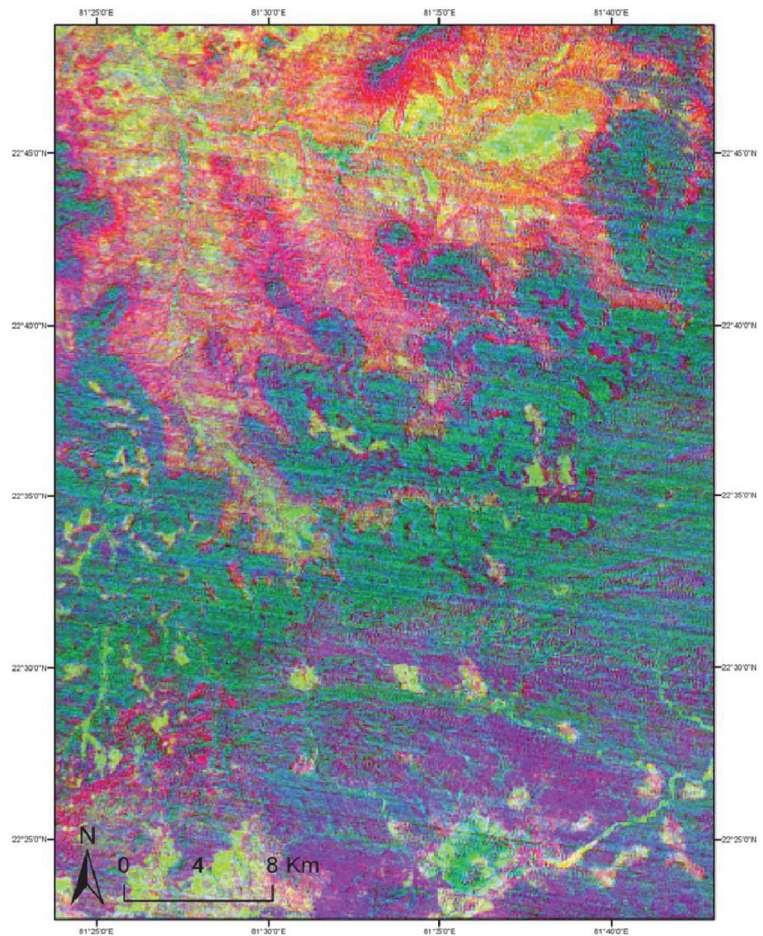

Figure 4. PCA image

\section{RESULTS AND DISCUSSION}

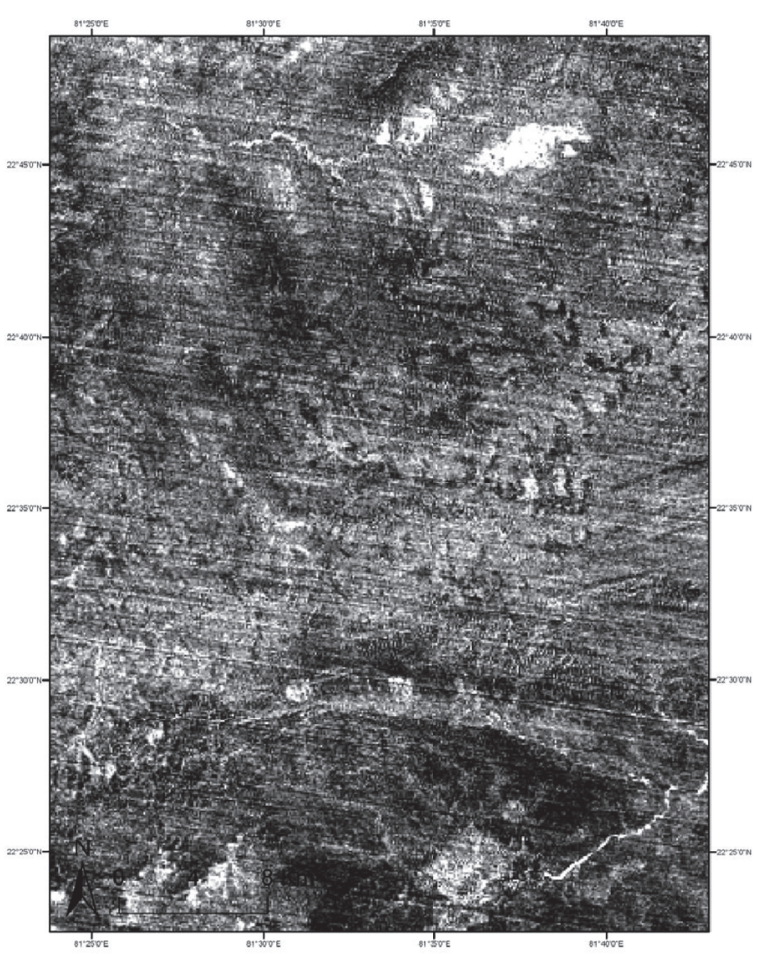

Figure 5. QRI image

ASTER TIR bands are quite effective to detect silicate and carbonate rocks, while bands 10 and 12 are particularly effective for detecting quartz absorption features and band 14 records high emissivity (Pour and Hashim 2012b; Surip et al. 2015). The positive eigenvalues reflect that the band plays a major role in the variation of a particular component while negative eigenvalues reflect a minor role to the variation of the derived component. The quartz content is reflected by thermal bands 10 and 12 of ASTER data due to high absorption property and by thermal band 14 due to high emissivity. It means that the eigenvalues of bands 10 and 12 have positive signs while band 14 is negative (Pour and Hashim 2011b).

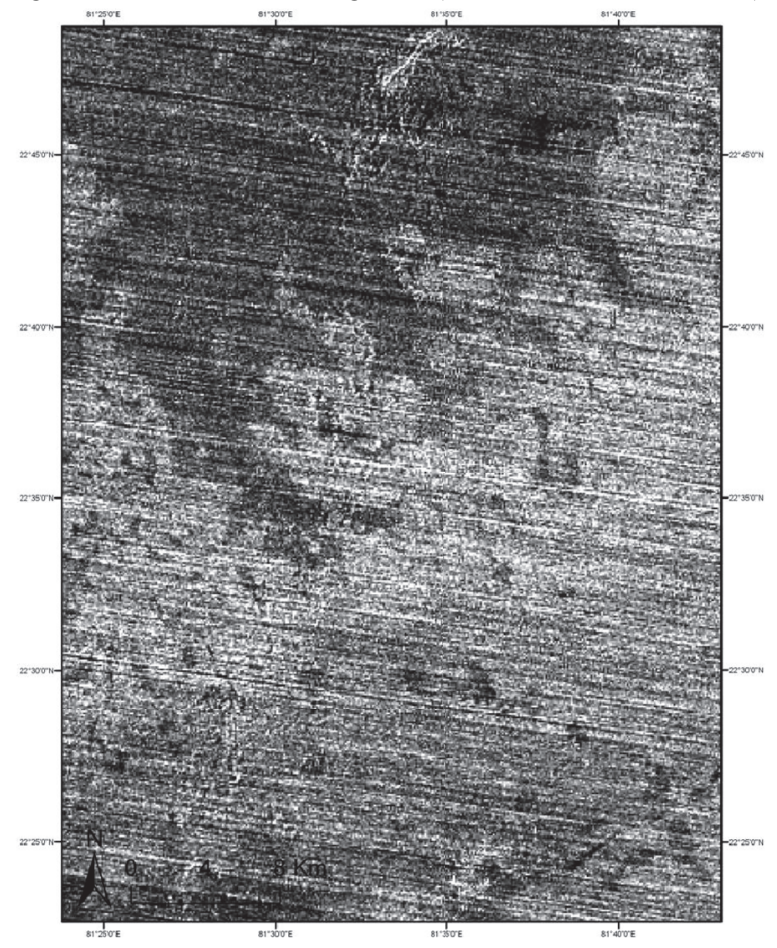

Figure 6. FRI image

Quartz rock index (QRI), felsdar rock index (FRI), and Mafic rock index (MRI), propounded by Guha and Kumar (2016) were applied in this study. It was observed that silica variation in alkali-granite and granite was enhanced in the QRI image. Quartz rich alkali granite appeared brighter in QRI image (Fig. 5 ). This quartz rock also appeared as bright green colour in PCA image. This is due to the fact quartz and feldspar are characterized with contrasting emissivity features in these bands. Therefore, it was difficult to indicate quartz enrichment in rocks which were rich in feldspar and quartz using band 11 and band 12. In FRI image, feldspar enriched alkali granite was brighter than darker granitic patch as alkali granite was relatively rich in alkali feldspar (Fig. 6). MRI images highlighted the mafic rocks in the study area (Fig. 7). 


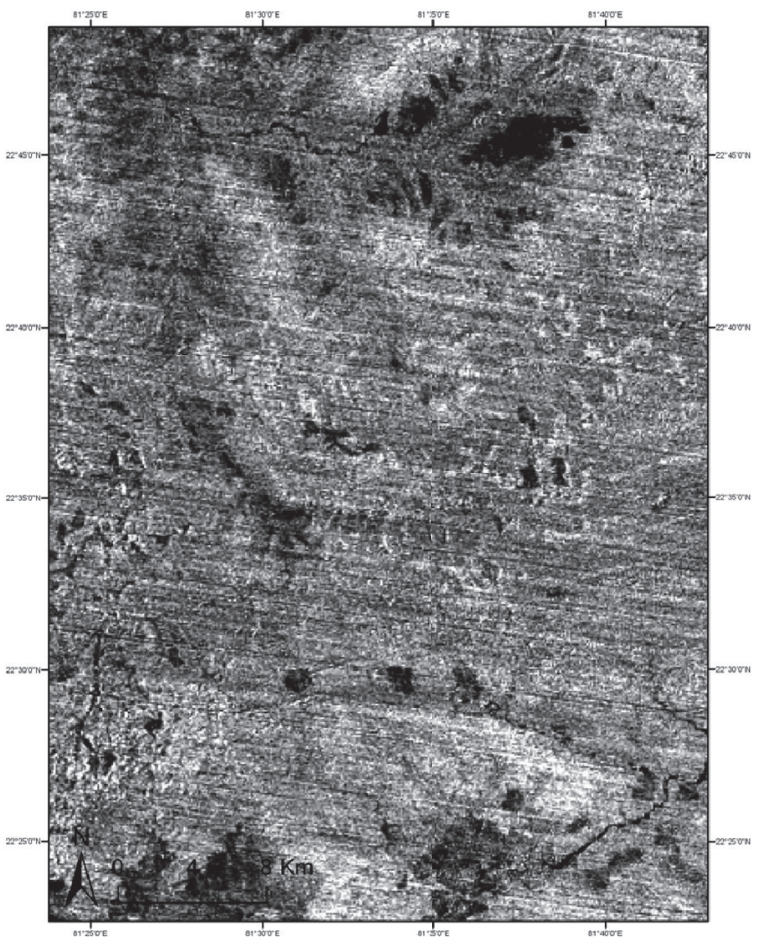

Figure 7. MRI image

Here, PC1, PC3, and PC4 satisfied the enabling conditions to identify quartz-rich and quartz-poor rocks. Results present that, ASTER TIR bands have the high capability to differentiate between different categories of rock and their quartz content using PCA spectral transformation. The results may have spatial and seasonal variations due to the presence or absence of the controlling factors of mechanical or chemical weathering.

\begin{tabular}{|l|l|l|l|l|l|}
\hline Eigenvector & PC1 & PC2 & PC3 & PC4 & PC5 \\
\hline Band10 & 0.39 & -0.31 & -0.78 & 0.38 & -0.01 \\
\hline Band11 & 0.43 & -0.31 & -0.06 & -0.82 & 0.21 \\
\hline Band12 & 0.48 & -0.54 & 0.61 & 0.37 & -0.07 \\
\hline Band13 & 0.49 & 0.45 & 0.02 & -0.16 & -0.73 \\
\hline Band14 & 0.48 & 0.56 & 0.10 & 0.19 & 0.64 \\
\hline \% of variance & 99.49 & 0.34 & 0.08 & 0.04 & 0.03 \\
\hline
\end{tabular}

Table 2. PCA for five ASTER TIR bands

\section{CONCLUSION}

ASTER TIR bands may be used successfully to detect different rocks and their quartz content richness. Guha's QRI image was very effective in identifying the quartz content in rocks alongwith the PCA image. FRI and MRI images were also supported a lot to detect the feldspar and mafic rocks, respectively which can be regarded as useful tool in signifying the quartz content of rocks. These lithological indices are important as it could delineate variation in the content of quartz, feldspar and mafic minerals in granitoids. Generally, it may be stated that quartz mineral was not uniformly presented among the different rocks. The results were significantly comparable to the published geological map.

\section{ACKNOWLEDGEMENTS}

Authors are thankful to United States Geological Survey (USGS).

\section{REFERENCES}

Bertoldi, L., Massironi, M., Visona, D., Carosi, R., Montomoli, C., Gubert, F., et al., 2011. Mapping the Buraburi granite in the Himalaya of Western Nepal: remote sensing analysis in a collisional belt with vegetation cover and extreme variation of topography. Remote Sens. Environ. 115 (5), pp. 1129-1144

Bose, M.K., 1997. Igneous Petrology. World Press, Kolkata.

Ding, C., Liu, X., Liu, W., Liu, M., Li, Y., 2014. Mafic and ultramafic and quartz-rich rock indices deduced from ASTER thermal infrared data using a linear approximation to the Planck function. Ore Geol. Rev. 60, pp. 161-173

Farmer, V.C. (Ed.), 1974. The Infrared Spectra of Minerals, 4. Mineralogical Society, London, p. 539

Gad, S., Kusky, T. 2007. ASTER spectral ratioing for lithological mapping in the Arabian-Nubian shield, the Neoproterozoic Wadi Kid area, Sinai, Egypt. Gondwana Research, 11 (3), pp. 326-335

Guha, A., Kumar, V.K., 2016. New ASTER derived thermal indices to delineate mineralogy of different granitoids of an Archaean Craton and analysis of their potentials with reference to Ninomiya's indices for delineating quartz and mafic minerals of granitoids - An analysis in Dharwar Craton, India. Ore Geol. Rev. 74 , pp. 76-87

Kahle, A.B., 1976. Thermal inertia imaging: a new geologic mapping tool. Geophys. Res. Lett. 3, pp. 419-421

Lyon, R.J.P., 1972.Infrared spectral emittance in geological mapping: airborne spectrometer data from Pisgah Crater. Science 7, 983-986.

Matar, S.S., Bamousa, A.O., 2013.Integration of the ASTER thermal infra-red bands imageries with geological map of Jabal Al Hasir area, Asir Terrane, the Arabian Shield. J. Taibah Univ. Sci. 7 (1), 1-7.

Ninomiya, Y., Fu, B., Cudahy, T.J., 2005.Detecting lithology with Advanced Spaceborne Thermal Emission and Reflection Radiometer (ASTER) multispectral thermal infrared radianceat-sensor data. Remote Sens. Environ. 99, 127-139.

Pour, A.B., Hashim, M. 2011a. Application of advanced spaceborne thermal emission and reflection radiometer (ASTER) data in geological mapping. International Journal of Physical Sciences, 6 (33), pp. 7657-7668

Pour, A.B., Hashim, M. 2011b. Identification of hydrothermal alteration minerals for exploring of porphyry copper deposit using ASTER data, SE Iran. Journal of Asian Earth Sciences, 42 (6), pp. 1309-1323

Pour, A.B., Hashim, M. 2012a. The application of ASTER remote sensing data to porphyry copper and epithermal gold deposits. Ore Geology Reviews, 44, pp. 1-9 
Pour, A.B., Hashim, M. 2012b. Identifying areas of high economic potential copper mineralization using ASTER data in the Urumieh-Dokhtar Volcanic Belt, Iran. Advances in Space Research, 49 (4), pp. 753-769

Rowan, L.C., Mars, J.C., Simpson, C.J., 2005.Lithologic mapping of the Mordor, NT, Australia ultramaficcomplex by using the Advanced Spaceborne Thermal Emission and Reflection Radiometer (ASTER). Remote Sens. Environ. 99 (12), 105-126.

Salisbury, J.W., Walter, L.S., 1989.Thermal infrared (2.5$13.5 \mu \mathrm{m})$ spectroscopic remote sensing of igneous rock types on particulate planetary surfaces. J. Geophys. Res. 94 (B7), 9192 9202.

Son, Y.-S., Kang, M.-K., Yoon, W.-J., 2014.Lithological and mineralogical survey of the Oyu Tolgoi region, South-eastern Gobi, Mongolia using ASTER reflectance and emissivity data. Int. J. Appl. Earth Obs. Geoinf. 26, 205-216.

Surip, N., Hamzah, A.H., Zakaria, M.R., Napiah, A., Talib, J.A 2015. Mapping of gold in densely vegetated area using remote sensing and GIS techniques in Pahang, Malaysia. Open Geosciences, 7, pp. 149-161

Tornabene, L.L., Moersch, J.E., Osinski, G.R., Lee, P., Wright, S.P. 2005. Spaceborne visible and thermal infrared lithologic mapping of impact-exposed subsurface lithologies at the Haughton impact structure, Devon Island, Canadian High Arctic: applications to Mars. Meteoritics and Planetary Science, 40 (12), pp. 1835-1858

vanderMeer, F.D., vanderWerff , H.M.A., vanRuitenbeek, F.J.A., et al. 2012. Multi and hyperspectral geologic remote sensing: a review. International Journal of Applied Earth Observation and Geoinformation, 14 (1), pp. 112-128 